\title{
CLIMATE LIMITATIONS OF THE BEECH (FAGUS SYLVATICA) WITHIN THE REPUBLIC OF MOLDOVA TERRITORY
}

\author{
Nedealcov Maria, Donica Ala* \\ Institute of Ecology and Geography, Chisinau, Republic of Moldova; \\ *Corresponding author: Donica Ala, e-mail: ieg@asm.md;
}

Received March 2019; Accepted April 2019; Published July 2019;

DOI: https://doi.org/10.31407/ijees9307

\begin{abstract}
Beech forests in the Republic of Moldova represent their East areal in the spatial distribution within Europe and occupy about 400 ha. In the trend of unfavorable changes in the climate conditions (summer mean temperature has increased, while the annual rainfall has shown a decreasing trend in Moldova) beech stands are face to climatic constraints in their distribution and development. Therefore, based on a set of climatic indices (Forest Aridity Index - FAI; DeMartonne Index - IM; Ellenberg Quotient - EQ; and Beech tolerance index - $\mathrm{Q}_{\text {втI }}$ ) was explain causes of beech surface decreasing in Moldova. The competitiveness of beech is limited by increasing water stress and it is replaced by forests consist of more drought-tolerant species. Per general, beech stands in Moldova, are growing in climatic conditions expressed by FAI values between 5.8-7.5; IM values greater than 32.0; EQ values - 27.0-30.0 and Qвті values - 15.0-17.0 units. Vitality of beech in "Plaiul Fagului" and "Codrii" Reservations (areas that include almost all beech stands from our country) is negatively affected by the impact of biotic and anthropic factors, and from abiotic factors - climate aridization leaves more and more fingerprints in the compositional structure of the forest ecosystems in the region.
\end{abstract}

Key words: climate indices, xeric limit, beech stands, distribution area. 